\title{
KEWAJIBAN DAN TANGGUNG JAWAB MEMENUHI PRESTASI DALAM HUKUM JAMINAN
}

\author{
Inri Januar ${ }^{1}$
}

\begin{abstract}
Law has an important role in the world economy, because the presence of lenders have made the position of the legal protection of the guarantee provided by the debtor. It should be alert to who is obliged to meet the achievement, and who is responsible for fulfilling achievement, it is to see if the position of individual guarantees directly replace the debtor at the time of default. Assurance also give priority to who is to first get the fulfillment of receivables if the debtor has turned out to be propagators of the creditor and the debtor turns out possessions is not enough to meet all its debts.
\end{abstract}

\section{Kata Kunci: tanggung jawab memenuhi prestasi}

\section{Pendahuluan}

Dalam dunia bisnis para pelaku ekonomi tidak dapat lepas dari ketergantungan keuangan atau modal dari pelaku ekonomi lainnya, hubungan seperti ini disebut juga hubungan hukum yang berarti harus ada aturan main yang dibuat guna melindungi kepentingan masing-masing pihak. Apabila salah satu pihak berhak atas prestasi (kreditur) tentu saja pihak yang lain berkewajiban memenuhi prestasi (debitur), apabila tidak terpenuhinya prestasi maka pihak debitur haruslah dinyatakan wanprestasi atau ingkar janji. Terhadap wanprestasi agar dapat dipenuhinya prestasi maka kreditur akan mengajukan pemenuhan prestasi baik dengan meminta ke pengadilan atau bisa saja mengeksekusi barang jaminan yang diberikan oleh debitur karena sudah melekatnya titel eksekutorial. Untuk itu maka perlulah dipahami pembatasan mengenai bentuk jaminan yang dapat diberikan, lalu kedudukan jaminan itu sendiri didalam hukum seperti apa dan apakah juga kreditur kedudukannya sama antara yang satu dengan yang lain.

Jaminan mempunyai kedudukan dan manfaat yang sangat penting dalam menunjang pembangunan ekonomi, karena keberadaan lembaga ini dapat memberikan manfaat bagi kreditur berupa terwujudnya keamanan terhadap transaksi dagang serta memberikan kepastian hukum bagi kreditur. ${ }^{2}$

Pada faktanya dalam dunia bisnis para lembaga keuangan baik bank maupun bukan bank menginginkan jaminan yang lebih dari jaminan kebendaan saja, oleh karenanya hukum juga menyediakan jaminan perorangan, jaminan tanggung-renteng dan garansi. Untuk membuat jaminan kebendaan lebih mempunyai nilai disaat terjadinya gagal bayar oleh debitur maka benda yang dijaminkan harus dilekatkan kepada lembaga jaminan, dalam hukum perdata lembaga jaminan dikenal dengan gadai dan hipotek dan karena kebutuhan yang lebih lagi maka lahirlah lembaga jaminan fiducia dan hak tanggungan yang dibedakan karena ada perbedaan antar benda bergerak dan benda tidak bergerak.

Hukum jaminan tidak menilai kreditur yang terlebih dahulu mempunyai piutang menjadi kreditur yang memliki hak istimewa atau didahulukan (preference), akan tetapi hukum jaminan memberikan penilaian prioritas terhadap kreditur yang memegang jaminan kebendaan dari debitur (separatis) untuk terlebih dahulu mendapatkan pemenuhan piutangnya. Jaminan perorangan dengan mana pihak ketiga ikut untuk mengikatkan dirinya bagi pemenuhan kewaji-

\footnotetext{
${ }^{2}$ Sri Soedewi Masjhoen Sofwan, Hukum Jaminan di Indonesia Pokok-Pokok Hukum dan Jaminan Perorangan, Jakarta : BPHN Departemen Kehakiman RI, 1980, hal.2
} 
ban debitur mempunyai jaminan yang lebih luas dibandingkan jaminan kebendaan, karena dalam jaminan perorangan berarti seluruh harta si penanggung menjadi jaminan bagi pemenuhan perikatan, hal ini berbeda dengan jaminan kebendaan yang mana pemenuhan perikatan hanya sebatas nilai dari kebendaan yang telah dijaminkan, sehingga kreditur tidak dapat menuntut lebih dari benda yang telah menjadi jaminan oleh debitur.

Terhadap perjanjian penanggungan akan menimbulkan pertanyaan baru terkait dengan apakah si penanggung langsung saja yang memenuhi perikatan apabila debitur gagal memenuhi kewjibannya. Hal ini tentu saja harus dilihat baik dari teori maupun hukum positif mengenai sampai sejauh manakah pertanggung jawaban si penanggung terhadap perikatan debitur dengan kreditur.

\section{Permasalahan}

1. Apa sajakah yang dapat dikategorikan sebagai jaminan?

2. Siapakah yang harus memenuhi dan bertanggung jawab terhadap prestasi?

\section{Tujuan Penulisan}

1. Untuk mengetahui apa sajakah yang dapat diklasifikasikan sebagai jaminan.

2. Untuk mengetahui pembatasan antara subyek hukum yang harus memenuhi prestasi dengan subyek hukum yang harus bertanggung jawab terhadap prestasi.

\section{Perikatan yang Lahir karena Perjanjian}

Dalam pergaulan hidup sehari-hari masyarakat dominan mengenal istilah perjanjian daripada perikatan, padahal dalam buku ketiga KUHPerdata menyebutkan judulnya adalah perikatan. Hal ini memang mungkin saja dapat terjadi, karena perikatan tidaklah memiliki batasan sementara mengenai perjanjian jelas mewajibkan adanya syarat-syarat yang harus dipenuhi sebagaimana yang tertuang didalam pasal 1320 KUHPerdata yang menjadi acuan untuk dapat menyebutkan bahwa hal tersebut adalah perjanjian.

Perikatan itu sendiri bersifat abstrak karena dapat lahir dari perjanjian maupun persetujuan. Pada umumnya perikatan yang lahir dari perjanjian merupakan perikatan yang sering terjadi dibandingkan perikatan yang lahir dari undang-undang daripada perikatan yang lahir dari undang-undang. Jika perikatan yang lahir dari perjanjian dapat dituntut dimuka hakim apabila si debitur melakukan wanprestasi sementara untuk perikatan yang lahir karena undangundang dapat dituntut dimuka pengadilan apabila salah satu pihak melakukan perbuatan melawan hukum sebagaimana yang disebutkan dalam rumusannya di pasal 1365 KUHPerdata yang berbunyi "tiap perbuatan yang melanggar hukum, yang membawa kerugian kepada seorang lain, mewajibkan orang yang karena kesalahannya menerbitkan kerugian itu, mengganti kerugian tersebut".

Buku III KUHPerdata tidak memberikan suatu rumusan mengenai batasan perikatan, jika dilihat pasal 1233 KUHPerdata hanya ditemukan persetujuan dan undang-undanglah yang melahirkan perikatan. Kemudian undang-undang dapat dibagi menjadi undang-undang saja maupun undang-undang karena adanya perbuatan manusia, sementara perbuatan manusia ada juga perbuatan yang halal dan perbuatan yang melawan hukum. Menurut ilmu pengetahuan hukum, perikatan adalah hubungan yang terjadi antara dua orang atau lebih yang terletak didalam lapangan harta kekayaan, dimana pihak yang satu berhak atas prestasi dan pihak lainnya wajib memenuhi prestasi. Maka unsur yang ada dalam perikatan adalah hubungan hubungan hukum, pihak-pihak, kekayaan, prestasi.

Tidak semua hubungan hukum dapat disebutkan sebagai perikatan. Suatu janji untuk bersama-sama pergi piknik, tidak melahirkan perikatan, sebab jan- ji tadi tidak mempunyai arti hukum, janji demikian masuk kedalam lapangan moral, dimana tidak dipenuhinya prestasi akan menimbulkan reaksi dari dan oleh angota-angota masyarakat lainnya, jadi pelaksanaannya bersifat otonom dan sosiologis.

Apa yang diapakai sebagai kriteria kekayaan tidaklah tetap, dahulu hal itu dinilai dengan uang atau tidak. Apabila hubungan hukum itu dapat dinilai dengan uang maka hubungan hukum itu adalah suatu perikatan. Tidak semua hubungan hukum dapat dini- 
lai dengan uang, namun apabila tidak ada akibat hukumnya akan membuat rasa keadilan tidak terpenuhi. Oleh karenanya kriteria kekayaan tidaklah terbatas dengan nilai uang tetapi kalau masyarakat menghendaki agar suatu hubungan hukum ada akibatnya maka hukum pun akan melekatkan akibat hukum pada hubungan tadi. ${ }^{3}$

Pihak disini adalah subyek hukum yang terdiri dari dua orang atau lebih. Pihak yang satu berhak atas prestasi atau disebut kreditur atau orang yang berpiutang dan pihak yang lainnya berkewajiban memberikan prestasi disebut juga debitur atau si berutang. Didalam perikatan pihak kreditur dan debitur dapat diganti, untuk penggantian debitur haruslah ada persetujuan kreditur sementara untuk penggantian kreditur dapat terjadi secara sepihak bahkan untuk hal-hal tertentu. Tentu saja pihak disini adalah subyek hukum yang cakap dalam melakukan perbuatang hukum dan juga berwenang melakukan perbuatang hukum untuk dirinya sendiri maupun bisa untuk orang lain.

Pasal 1234 jelas menyebutkan apa yang dikategorikan sebagai prestasi yaitu:

1. Untuk memberikan sesuatu: memberikan suatu barang yang menjadi obyek dalam perjanjian, contoh A harus memberikan barang kepada B dalam perikatan jual beli.

2. Untuk berbuat sesuatu: berbuat mempunyai artian melakukan sesuatu, apa yang dilakukan dengan tidak memberikan sejumlah barang tetapi memberikan jasa, contoh A membangun rumah B.

- Untuk tidak berbuat sesuatu: A membuat perjanjian dengan B ketika menjual apotiknya, untuk tidak menjalankan usaha apotik dalam daerah yang sama.

Pasal 1381 menyebutkan perikatan hapus karena adanya:

- Pembayaran

- Penawaran pembayaran tunai/penitipan (konsinyasi)

\footnotetext{
${ }^{3}$ Mariam Darus Barulzaman, "Hukum Perikatan Dengan Penjelasan”, Bandung: Alumni, 2011.
}

- Novasi/pembaruan utang

- Perjumpaan utang/kompensasi

- Konfisio/percampuran utang

- Pembebasan utang

- Musnahnya barang yang terutang

- Kebatalan dan pembatalah perjajnjian

- Berlakunya syarat batal

- Lewatnya waktu/kedaluwarsa

Memanglah sangat nyata bahwa hubungan antara seseorang yang ingin mengikatkan dirinya dengan seorang lainnya dibuat didalam perjanjian, sehingga mendapatkan pembatasan antara hak dan kewajiban diantara para pihak. Menurut pasal 1320 KUHPerdata syarat sahnya perjanjian adalah "sepakat mereka yang mengikatkan dirinya, kecakapan untuk membuat suatu perikatan, suatu hal tertentu dan suatu sebab yang halal".

Perjanjian yang dibuat oleh para pihak dapat saja menimbulkan perjanjian turunan, apabila memang didalam perjanjian tersebut dimasukkan jaminan terhadap kebendaan sebagai pemenuhan kewajiban, misalnya dalam perjanjian peminjaman uang, sekarang ini pemilik sangat menginginkan barang sebagai jaminan dalam peminjaman uang, ini dimaksud untuk mempermudah kreditur dalam memenuhi prestasinya terhadap debitur dan untuk memiliki hak privelege dalam posisi antar para kreditur, ini karena hukum perjanjian mempunyai sistem terbuka dan juga dengan adanya asas kebebasan berkontrak yang dianut sehingga para pihak dapat saja memodifikasi bentuk atau membuat perjanjian-perjanjian diluar dari apa yang dikenal dalam KUHPerdata asalkan tidak bertentangan dengan peraturang perundang-undangan, kesusilaan dan adat istiadat, bentuk perjanjian yang seperti ini dikenal dengan perjanjian tidak bernama.

Kekuatan hukum perjanjian adalah sama dengan undang-undang, ini dapat terjadi karena didalam perjanjian dikenal asas pacta sunt servanda yang artinya adalah perjanjian yang dibuat itu adalah sebagai undang-undang bagi yang membuatnya, yang berarti para pihak yang telah mengikatkan diri dalam perjanjian itu harus tunduk dan patuh dalam melaksanakan kewajibannya atau isi dari perjanjian. 


\section{Jaminan}

Kehadiran lembaga jaminan sangatlah penting bagi pihak-pihak yang ingin memberikan fasilitas kredit bagi pihak lain tanpa harus khawatir akan kemampuan dari debitur untuk dapat melunasi kewajibannya, karena dengan hadirnya lembaga jaminan maka kreditur cukup mendapatkan barang yang menjadi jaminan atau telah dijaminkan gunan memenuhi kewajiban si debitur. Tentu saja ini merupakan hal yang positif untuk dapat melindungi pemilik modal, serta berguna untuk kepastian hukum, karena dengan dibebankannya suatu barang terhadap jaminan maka si kreditur telah mempunyai hak eksekutorial, yang artinya adalah hak untuk mengeksekusi barang yang dijaminkan. Kata mengeksekusi disini memiliki arti untuk mengambil barang yang dijaminkan kemudian menjualnya untuk pemenuhan kewajiban debitur. Penjualan yang dilakukan biasanya dengan lelang jadi bukan jual beli sebagaimana lazimnya terjadi dalam kehidupan sehari-hari, ini dilakukan juga untuk melindungi kepentingan debitur agar mendapatkan harga tertinggi dari barangnya yang akan dijual. Hak mengeksekusi disini bukan berarti hak untuk memiliki barang milik debitur, tetapi barang tersebut dijual apabila ada kelebihan uang dari hasil penjualan barang tersebut setelah diambil untuk memenuhi kewajiban si debitur maka wajib dikembalikan oleh kreditur kepada debitur, karena itu merupakan hak debitur.

Dalam hukum kebendaan selain memberikan hak-hak untuk memberi kenikmatan terdapat juga hak-hak yang memberi jaminan. Jaminan yang diberikan hak kebendaan pada dasarnya terjadi atas benda milik orang lain . hak jaminan atas benda milik orang lain itu menurut KUHPerdata antara lain gadai dan hipotek, serta yang timbul diluar KUHPerdata adalah jaminan fidusia dan hak tanggungan atas tanah beserta benda-benda yang berkaitan dengan tanah. Selain hak-hak yang termasuk dalam kedua kelompok tersebut diatas, juga dikenal hak-hak yang bukan merupakan hak kebendaan tetapi mempunyai sifat kebendaan dan memberikan jaminan, yaitu hak istimewa (privilege) dan hak menahan (retentie).

Selain untuk memberikan ketenangan terhadap pemenuhan perjanjian, penerapan jaminan juga dapat dibedakan terhadap dua benda yang berbeda, yaitu benda yang bergerak dan benda yang tidak bergerak. Jika didalam pasal 1150 KUHPerdata pembebanan jaminan terhadap benda bergerak harus dilakukan dengan gadai dan pembebanan jaminan terhadap benda tidak bergerak harus dilakukan dengan hipotik. Namun sejak diberlakukannya undang-undang hak tanggungan, maka tanah beserta benda-benda yang berkaitan dengan tanah hanya dapat dibebankan dengan hak tanggungan, sedangkan ketentuan tentang hipotik dalam buku ke II KUHPerdata hanya dapat dibebankan atas pesawat dan helikopter.

Istilah hukum jaminan berasal dari terjemahan $z a$ kerheidsstelling atau security of law. Dalam seminar Badan Pembinaan Hukum Nasional tentang lembaga hipotek dan jaminan lainnya, yang diselenggarakan di Yogyakarta ,pada tanggal 20 sampai dengan 30 juli 1977, disebutkan bahwa hukum jaminan, meliputi pengertian baik jaminan kebendaan maupun jaminan perorangan. Pengertian jaminan ini mengacu pada jenis jaminan, bukan pengertian. Definisi ini menjadi tidak jelas, karena yang dilihat hanya dari penggolongan jaminan.

Hukum jaminan mempunyai makna yang lebih luas dan umum serta bersifat mengatur dibandingkan dengan hak jaminan seperti halnya hukum kebendaan yang mempunyai ruang lingkup yang lebih luas dan mempunyai sifat mengatur dari pada hak kebendaan. Melihat kepada Kitab Undang-Undang Hukum Perdata maka kita tidak akan temukan arti atau definisi mengenai jaminan, yang ada adalah rumusan sebagaimana disebutkan dalam pasal 1131 KUHPer. ${ }^{4}$ Beberapa pakar hukum memberikan pengertianmengenai jaminan, sebagai berikut:

- Mariam Darus Badrulzaman merumuskan jaminan sebagai suatu tanggungan yang diberikan oleh seorang debitur dan atau pihak ketiga kepada kreditur untuk menjamin kewajibannya dalam suatu perikatan. ${ }^{5}$

\footnotetext{
${ }^{4}$ Frieda Husni Hasbullah, Hak-Hak Yang Memberi Jaminan (Jilid 2), Jakarta: Ind Hill CO, 2009, hal.6

${ }^{5}$ Mariam Darus Barulzaman, "Permasalahan Hukum Hak Jaminan", Hukum Bisnis (Volume 11, 2000).
} 
- J. Satrio berpendapat bahwa hukum jaminan adalah peraturan hukum yang mengatur tentang jaminan-jaminan piutang seorang kreditur terhadap seorang debitur. ${ }^{6}$

- Thomas Suyatno, ahli perbankan menyatakan bahwa jaminan adalah penyerahan kekayaan atau pernyataan kesanggupan seseorang untuk menanggung pembayaran kembali suatu barang. ${ }^{?}$

- Hartono Hadisaputro menyatakan jaminan adalah sesuatu yang diberikan debitur kepada kreditur untuk menimbulkan keyakinan bahwa debitur akan memenuhi kewajiban yang dapat dinilai dengan uang. ${ }^{8}$

Pasal 1131 KUHPer merupakan sifat pelengkap, pasal ini bisa diterapkan dengan menyimpang terhadap pasal 1820 KUHPer. Dengan demikian tanggungjawab yang diletakkan oleh pasal ini ke debitur dapat saja tidak melekat kepada debitur akan tetapi melekat kepada pihak ketiga pada awal perjanjian jaminan dibuat untuk bertanggung jawab atas pemenuhan prestasi.

\section{Sifat Perjanjian Jaminan}

Perjanjian jaminan haruslah dibuat atas dasar adanya perjanjian pokok, oleh karenanya sifat accessoir dari jaminan dapat menimbulkan akibat hukum yaitu accessoir bergantung kepada perjanjian pokokonya. Perjanjian tambahan ini dimaknakan agar keamanan kreditur lebih terjamin dan bentuknya dapat berupa jaminan kebendaan maupun jaminan peroarangan. ${ }^{9}$ Sifat accesoir dari jaminan dapat menimbulkan akibat hukum sebagai berikut:

- Adanya dan hapusnya perjanjian tambahan tergantung pada perjanjian pokok

- Jika perjanjian pokok batal, maka perjanjian tambahan juga batal

- Jika perjanjian pokok beralih, maka perjanjian tambahan juga ikut beralih

${ }^{6}$ J. Satrio, Hukum Jaminan, Hak-Hak Jaminan Kebendaan, Bandung: Citra Aditya Bakti, 1991, hal.3

${ }^{7}$ Thomas Suyatno, Dasar-Dasar Perkreditan, Jakarta: Gramedia, 1989, hal. 70

${ }^{8}$ Hartono Hadisaputro, Pokok-Pokok Hukum Perikatan dan Hu-
- Jika perjanjian pokok beralih karena cessie, subrogatie maka perjajnian tambahan juga beralih tanpa penyerahan khusus

\section{Macam-Macam Jaminan}

Jaminan dapat dibedakan menjadi jaminan umum dan jaminan khusus. Jaminan umum adalah jaminan yang diberikan bagi kepentingan semua kreditur dan menyangkut sema harta kekayaan debitur, hal ini berarti benda jaminan tidak diperuntukkan bagi kreditur tertentu dan hasil dari penjualannya dibagi diantara para kreditur seimbang dengan piutangnya masingmasing ${ }^{10}$, Jaminan umum dapat dilihat dari pasal 1131 dan 1132 KUHPerdata, jika melihat pasal ini maka dapat dilihat seluruh kebendaan debitur menjadi tanggungan tanpa harus adanya perjanjian mengenai hal ini dan benda jaminan tidak diperuntukkan bagi kreditur tertentu serta hasil dari penjualannya dibagi diantara para kreditur menurut keseimbangan dengan piutangnya masing-masing. Akan tetapi ada juga jaminan khusus yang dapat memberikan posi- si istimewa kepada kreditur apabila memang harta milik debitur tidak cukup untuk menyelesaikan tanggung jawabnya kepada para kreditur. Jaminan khusus itu tercermin dalam pasal 1132-1134 KUHPerdata KUHPerdata, sehingga membuat kedudukan kreditur menjadi tidak seimbang akan tetapi lebih memberikan kenyamanan karena kreditur tidak akan memiliki rasa ketakutan apabila debitur memiliki lebih dari satu kreditur.

Jaminan khusus dibagi menjadi dua macam jaminan yaitu jaminan perorangan (personal guaranty) dan jaminan kebendaan (Zakelijke). Jaminan perorangan dapat dilihat pada title ketujuh belas KUHPerdata tentang penanggungan (borgtocht) selain itu ada juga perjanjian garansi yang diatur didalam 1316 KUHPerdata. Jaminan perorangan merupakan jaminan yang menimbulkan hubungan langsung dengan orang tertentu atau pihak ketiga artinya tidak memberikan hak untuk didahulukan pada benda-benda tertentu, karena harta kekayaan pihak ketiga tersebut hanyalah merupakan jaminan bagi terselenggaranya

\footnotetext{
${ }^{10}$ Frieda Husni Hasbullah, Op. Cit, hal.9
} 
suatu perikatan. ${ }^{11}$ Pasal 1820 Jo 1831 KUHPerdata menyatakan bahwa penanggung baru akan melakukan kewajibannya apabila si berutang lalai dan tidak mampu memenuhinya sedangkan benda-benda siberutang harus lebih dulu disita dan dijual untuk melunasi utangnya. ${ }^{12}$ Akan tetapi hal ini dapat dikesampingkan jika penanggung telah melepaskan hak-hak istimewanya. ${ }^{13}$

Berdasarkan pasal 1823 KUHPerdata seseorang dapat menjadi penanggung tanpa melalui permintaan orang yang ditanggungnya (deibutr) bahkan diluar pengetahuan debitur tersebut. Juga diperbolehkan menjadi penanggung tidak saja untuk berhutang utama tersebut, penanggung demikian dalam praktek disebut sub-penanggung (sub-guarantor) ${ }^{14}$. Penanggungan utang harus dinyatakan dengan pernyataan yang tegas tidak boleh dipersangkakan serta tidak diperbolehkan untuk memperluas penanggungan hingga melebihi ketentuan-ketentuan yang menjadi syarat sewaktu mengadakannya, demikian menurut ketentuan pasal 1824 KUHPerdata. Maksud diadakannya pernyataan yang tegas bukanlah berarti harus diadakan secara tertulis, dapat juga diadakan secara lisan namun hal ini dapat mempersulit kreditur untuk membuktikan sampai dimana kesanggupan si penanggung tersebut. Selain itu pernyataan tegas dapat mnelindungi si penanggung yang bersangkutan, karena dia tidak dapat diminta pertanggung jawaban atas hal-hal lain selain apa yang sudah diperjanjikan secara tegas itu. ${ }^{15}$

Jaminan kebendaan adalah jaminan yang memberikan kreditur kebendaan debitur hak untuk memanfaatkan benda tersebut apabila debitur lalai dalam melaksanakan kewajibannya. ${ }^{16}$ Benda yang dijaminkan dapat berupa benda bergerak dan benda tidak bergerak pembedaan kedua benda jaminan tersebut tentu saja membuat perbedaan lembaga jaminan yang dapat dilekatkan kepada benda jaminan terse- but, untuk benda bergerak dilekatkan jaminan gadai

\footnotetext{
${ }^{11}$ Ibid, hal.13

${ }^{12}$ Pasal 1820 Jo 1831 KUHPerdata

${ }^{13}$ Pasal 1832 KUHPerdata

${ }^{14}$ Frieda Husni Hasbullah, Loc. Cit. hal.15

${ }^{15}$ Ibid, hal.16

${ }^{16}$ Ibid, hal.18
}

dan fiducia, untuk benda tidak bergerak dapat diletakkan jaminan hak tanggungan. Dalam hal ini jika debitur wanprestasi maka, kreditur mempunyai hak didahulukan (preferant).

Perbedaan antara jaminan kebendaan dengan jaminan perorangan, adalah: ${ }^{17}$

a. Merupakan hak mutlak (absolut) atas suatu benda.

b. Kreditur memiliki hubungan langsung dengan benda-benda tertentu milik debitur.

c. Dapat dipertahankan terhadap tuntutan oleh siapapun.

d. Selalu mengikuti bendanya ditangan siapa benda itu berada (droit de suite).

e. Mengandung asas prioritas, yaitu hak kebendaan yang lebih dahulu terjadi akan lebih diutamakan daipada yang terjadi kemudian (droit de preference).

f. Dapat diperalihakan seperti hipotik.

g. Bersifat perjanjian tambahan.

Jika dibandingkan antara jaminan umum dan khusus maka dalam praktek perbankan ternyata jaminan khusus. Pasal 24 ayat 1 Undang-undang nomor 14 tahun 1967 menyatakan dengan tegas bahwa bank umum tidak diperkenankan memberikan kredit tanpa suatu jaminan (agunan) kepada siapapun. Dalam penjelasan ata undang-undang tersebut dinyatakan bahwa yang dimaksud dengan jaminan adalah jaminan dalam arti luas, yaitu jaminan yang bersifat materiil maupun inmateriil. Inmateriil dapat berupa watak maupun kemampuan debitur dalam bidang ekonomi, bagaimana keadaan administrasi dan jalannya perusahaan. Namun dalam perkembangannya melalui undang-undang yang baru yaitu nomor 7 tahun 1992 dan undnag-undang nomor 10 tahun 1998 tidak menyatakan secara tegas tentang keharusan adanya agunan dalam setiap pemberian kredit. Dengan demikian jika ditinjau dari sudut kreditur maka jaminan khusus dalah jaminan yang disukai karena memberikan kepastia kepada kreditur untuk mendapatkan kembali piutangnya melalui jaminan yang telah diserahkan oleh debitur dan juga karena adanya hak preferan artinya ada hak yang didahulukan bagi kreditur diatas kreditur lainnya dalam pemenuhan pembayaran hutang sebitur.

${ }^{17}$ Ibid, Hal.19 


\section{Schuld dan Haftung}

Dalam hubungan antara kreditur dan debitur, pada umumnya pihak debitur tidak hanya berkewajiban memenuhi prestasi (schuld) tetapi juga harus mempunyai jaminan (haftung), berdasarkan pasal 1131 dan 1132 KUHPerdata atas pelaksanaan kewajiban tersebut. Schuld adalah kewajiban debitur untuk berprestasi dan Haftung adalah menjamin pemenuhan prestasi tersebut dengan seluruh harta kekayaannya. Schuld dan Haftung selalu ada pada pihak debitursehingga sebagai konsekuensinya maka actio paulina hadir untuk pihak kreditur.

Setiap kreditur mempunyai piutang terhadap debitur. Untuk itu kreditur mempunyai hak menagih piutang tersebut. Didalam ilmu pengetahuan di samping hak menagih (Vorderingsrecht) apabila debitur tidak memenuhi kewajiban membayar hutangnya, maka kreditur mempunyai hak menagih kekayan debitur sebagai piutangnya pada debitur itu (verhaalsrecht). ${ }^{18}$ Menurut para sarjana Schuld dan Haftung itu dapat dibedakan tetapi tidak dapat dipisahkan.

Dengan demikian pengecualian-pengecualian dari schuld dan haftung adalah: ${ }^{19}$

1. Schuld tanpa Haftung; debitur berkewajiban memenuhi prestasi namun tidak bertanggungjawab terhadap pemenuhan tersebut.

Contoh: utang karena judi, tidaklah si debi- tur memiliki haftung karena dalam pasal 1788 KUHPerdata jelas menyebutkan undang-undang tidak memberikan suatu hak untuk menuntut yang diakibatkan karena adanya utang judi.

2. Schuld dan haftung terbatas; pewarisan dengan hak pendaftaran (Pasal 1037 KUHPerdata), ahli waris yang menerima warisan secara benafesier hanya berkewajiban membayar utang-utang yang ditinggalkan pewaris terbatas pada/seharga harta kekayaan yang ditinggalkannya. Terbatas terhadap harta yang ditinggalkan oleh pewaris untuk melunasi kewajibannya kepada para kreditur.

3. Haftung dengan Schuld pada orang lain; misalnya perjanjian penanggungan. Penanggung memberi-

\footnotetext{
${ }^{18}$ Mariam Darus B, Hukum Perikatan dengan Penjelasannya, Bandung : Alumni, 2010, hal. 10.

${ }^{19}$ R. Setiawan. Pokok-pokok Hukum Perikatan, Bandung : Putra A. Bardin, 1999, hal. 7
}

kan jaminan barangnya untuk dipakai sebagai jaminan oleh debitur terhadap kreditur. Dalam hal ini penanggung tidaklah mempunyai kewajiban memenuhi prestasi (yang mempunyai kewajiban adalah debitur), namun bertanggung jawab atas pemenuhan prestasi.

Contoh: A meminjam uang ke B dengan jaminan $\mathrm{C}$, kemudian A mempunyai niat jahat untuk membiarkan $\mathrm{C}$ membayar utang tersebut kepada $\mathrm{B}$, padahal sejatinya diketahui A mampu untuk membayar utang tersebut. Oleh karenanya maka haruslah si A terlebih dahulu yang mengusahakan dan berkewajiban untuk membayar ke B kemudian barulah apabila tidak mampu $\mathrm{C}$ lah yang mengambil posisi $\mathrm{A}$, akan tetapi ini semua bisa dihindarkan apabila $\mathrm{C}$ telah melepaskan semua hak istimewanya.

\section{Kesimpulan}

1. Selain benda, subyek hukum juga dapat menjadi jaminan atau penangung dalam suatu perjanjian antara kreditur dan debitur yang dikenal dengan jaminan perorangan, jaminan tanggung renteng dan garansi. Sistem tertutup dalam hukum jaminan jelas membuat para pihak tidaklah dapat membawa apa yang diingikannya apabila tidak diatur didalam Kitab Undang-Undang hukum Perdata maupun dalam undang-undanag yang menagatur mengenai hukum jaminan.

2. Pemisahan antara kewajiban memenuhi prestasi dan tanggung jawab memenuhi prestasi, dimana tanggung jawab memenuhi prestasi dapat diletakkan kepada pihak ketiga atau penanggung apabila debitur tidak mampu memenuhi kewajibannya dan penanggung telah melepaskan hak-hak istimewanya, Penanggungan utang harus dinyatakan dengan pernyataan yang tegas tidak boleh dipersangkakan. Karena KUHPerdata sifatnya sebagai pelengkap oleh karenanya sangat memungkinkan bagi pihak-pihak dalam perikatan untuk mengatur sendiri mengenai keinginannya dalam perikatan. 


\section{Saran}

1. Harus diperhatikan secara teliti jenis jaminan apa yang akan diberikan sesuai dengan kebutuhan agar tidak merugikan kepentingan debitur maupun kreditur.

2. Harus diperhatikan apakah memang si penan- ggung telah melepaskan hak istimewanya, agar kehadiran si penanggung tidaklah menjadi sia-sia dalam perikatan dan bisa melaksanakan perannya demi kepentingan kreditur.

\section{Daftar Pustaka}

\section{Buku}

Frieda Husni Hasbullah, Hukum Kebendaan Perda- ta, Hak-Hak yang Memberi Jaminan (Jilid 2), Jakarta: Ind Hill CO, 2009

Handri Raharjo, Hukum Perjanjian di Indonesia, Yogyakarta: Pustaka Yustisia, 2009

H. Riduan Syahrani, Seluk Beluk dan Asas-Asas Hu- kum Perdata, Bandung: Alumni, 2010

Hartono Hadisaputro, Pokok-Pokok Hukum Peri- katan dan Hukum Jaminan, Yogyakarta: Liberty, 1984, hal.50

Mariam Darus Badrulzaman, Hukum Perikatan den- gan Penjelasan, Bandung: Alumni, 2011

R. Setiawan, Pokok-Pokok Hukum Perikatan, Ban- dung: Putra A. Bardin, 1999

Sri Soedewi Masjhoen Sofwan, Hukum Jaminan di Indonesia Pokok-Pokok Hukum dan Jaminan Perorangan, Jakarta : BPHN Departemen Kehakiman RI, 1980

\section{Peraturan Perundang-Undangan}

Kitab Undang-Undang Hukum Perdata. 